\title{
Indicators of dental caries in teenagers attending various educational establishments
}

\author{
Ivanna I. Abramchuk', Lyudmila F. Kaskova', Viktor M. Batig', Yuliya H. Kilmukhametova² \\ ${ }^{1}$ Bukovinian State Medical University, Chernivtsi, Ukraine \\ ${ }^{2}$ Ukrainian Medical Dental Academy, Poltava, Ukraine
}

\begin{abstract}
Topicality. Dental diseases, as a rule, arise under the influence of various factors, which may include: bad oral hygiene, somatic diseases, biogeochemical features of the environment, socio-economic living conditions, quality and amount of nutrition of the population, organization of primary prevention.

Material and methods. The study of dental status was conducted according to the standard method in teenagers studying in different educational establishments of Chernivtsi (school, college, university). The prevalence (\%) and intensity of caries (CFR) was determined in each age group.

Results and discussions. The obtained data indicates on a difference in the rate of caries intensity in teenagers of different forms of education and in different age groups. Teenagers attending school are likely to have lower indices than college students.

Conclusions. Given the intensity of caries, we can assume that teenagers attend-ing college do not pay enough attention to the condition of the hard tooth tissues, which leads to an increase in the number of affected by caries teeth in each studied age period. This leads to a more detailed study of the risk factors for caries in teenagers attending various educational establishments and to plan preventative measures to increase the resistance of the hard tissues of their teeth.
\end{abstract}

Keywords: indicators of dental caries, teenagers, educational establishments

\section{INTRODUCTION}

Although therehave been improvements in the oral health of populations from several countries, there are still some global issues that require some actions to be overcome [1-5]. Dental caries is considered to be an important public health issue worldwide due to the pain and suffering caused to subjects, to the high cost of its treatment, and to the impact on quality of life. There is evidence that the disease distribution in the population of both developed and developing countries happens unequally, being strongly associated with socioeconomic conditions [3-7]. The oral health of 12-year-old schoolchildren has been investigated in epidemiological studies all around the world as an indicator of caries attack in permanent dentition. Usually, at school, a reliable and simpler operational sample can be obtained through the education system.
Tooth caries is a big problem today, the roots of which go back to the distant past, since this pathology has been discovered in ancient times, requiring a detailed study of the factors that contribute to its occurrence $[1,2,3,10-16]$.

Dental diseases, as a rule, arise under the influence of various factors, which may include: bad oral hygiene, somatic diseases, biogeochemical features of the environment, socio-economic living conditions, quality and amount of nutrition of the population, organization of primary prevention [6,7,9,17-20].

Recently, the impact of new forms of education (lyceums, gymnasiums, colleges, in-depth classes) on the general health of students and the possibility of influencing dental status has been highlighted in the scientific literature [1,4,5,21-26]. 


\section{MATERIAL AND METHODS}

The study of dental status was conducted according to the standard method (8) in teenagers studying in different educational establishments of Chernivtsi (school, college, university). The prevalence (\%) and intensity of caries (CFR) was determined in each age group.

The results of caries prevalence were interpreted according to the WHO nomenclature, where a value from 0 to $30 \%$ is considered as low prevalence, from 31 to $80 \%$ - medium and from 81 to $100 \%$ - high dental caries. The intensity level was determined by the indicators: very low $-0-1.1$; low $-1.2-2.6$; the average is $2.7-4.4$; high $-4.5-6.5$; very high 6.6 and upper. When comparing the indicators, the values at $\mathrm{p} \leq 0.05$ were considered probable.

\section{RESULTS}

In this study, inequalities in the distribution of caries among 12-year-old schoolchildren were seen in the analyzed city regarding contextual and individual factors. The more favorable situation among the highest socioeconomic groups confirms the influence of social determinants in the population's health pattern, which has been an object of growing interest in public health.

Availability of secondary data through local information systems enabled assessing the influence of contextual variables about the outcome. Besides considering the sampling design, the multilevel analysis enabled contemplating part of the complexity inherent to the health-disease process. The adopted hierarchical model considered aspects of contextual level as mediators of the entire individual determination network.

Owing to the limited number of contextual and individual variables collected in the epidemiological survey, other analyses that could better elucidate the factors that influence caries prevalence among 12-year-old schoolchildren in the city were not performed. Despite this limitation, this is one of the first studies to have applied the multilevel analysis for a representative group of children, in which the analyzed individual and contextual factors were useful for identifying vulnerable groups. This kind of analysis enables the investigators to deal with the microlevel of subjects and the macrolevel of groups simultaneously, contributing for a more effective and contextualized local oral health planning.

Our studies of the state of hard tissues of teeth in teenagers who study at different educational establishments of Chernivtsi (school, technical school, university) revealed that all of the examined had tooth caries (table 1). That showed that caries prevalence in all age groups was $100 \%$ independently of place of study. According to the WHO criterion, it is a high prevalence of dental caries.

The intensity of caries on the CPV of teeth in teenagers 15 years of age who attended school is 1.94 times lower (low intensity level) than in college teenagers (medium intensity level). Component "C" (untreated tooth caries) is 3.19 times higher than in schoolchildren. The number of treated teeth with schoolchildren is $70.2 \%$ of the CFR index, and that of college students is $50.9 \%$.

In teenagers 16 years-old attending school, the intensity of caries increases 1.35 times compared to the previous age period, ie $34 \%$ (average), and in students attending college 1.55 times $(54.8 \%)$ ) (very high). A greater increase in the intensity of caries in teenagers from 15 to 16 years old attending college can be observed, which requires a more detailed study of the causes of this phenomenon. We can assume that children who enter college are deprived of daily parental care, become more independent, and pay less attention to dental health.

In 16-year-old teenagers of different forms of learning the index significantly differs. Children attending school have a caries intensity of 2.28 times lower (122.8\%) than those who receive further education in college.

In this age period, the percentage of dental fillings in schoolchildren is $71.29 \%$, and in college students is $39.1 \%$ of the CFR index. This index remains the same for schoolchildren compared to 15-year-olds, and for college students it is deteriorating as some teenagers have removed permanent teeth $(0.16 \pm 0.3$ teeth $)$.

The obtained data indicates on a difference in the rate of caries intensity in teenagers of different forms of education and in different age groups. Teenagers attending school are likely to have lower indices than college students.

The next age group -17 years-old - is represented by teenagers attending college and 
TABLE 1. Indicators of caries of permanent teeth in teenagers $15-18$ years $(M \pm m)$

\begin{tabular}{|c|c|c|c|c|c|c|c|}
\hline \multirow[t]{2}{*}{ Age } & \multirow[t]{2}{*}{ Place of study. Amount } & \multicolumn{4}{|c|}{ Caries intensity (CFR of teeth) } & \multicolumn{2}{|c|}{ Prevalence. \% } \\
\hline & & CFR & C & $\mathrm{F}$ & $\mathrm{R}$ & abs. & $\%$ \\
\hline \multirow[t]{2}{*}{15} & school $n=53$ & $2.25 \pm 0.07$ & $0.67 \pm 0.07$ & $1.58 \pm 0.07$ & 0 & 53 & 100 \\
\hline & college $n=74$ & $4.36 \pm 0.08$ & $2.14 \pm 0.11$ & $2.22 \pm 0.09$ & 0 & 74 & 100 \\
\hline \multicolumn{2}{|r|}{ P15 school - college } & $P \leq 0.001$ & $P \leq 0.001$ & $P \leq 0.001$ & & & \\
\hline \multirow[t]{2}{*}{16} & school $n=54$ & $3.03 \pm 0.08$ & $0.94 \pm 0.14$ & $2.16 \pm 0.13$ & 0 & 54 & 100 \\
\hline & college $n=56$ & $6.75 \pm 0.26$ & $3.89 \pm 0.23$ & $2.64 \pm 0.08$ & $0.16 \pm 0.3$ & 56 & 100 \\
\hline \multicolumn{2}{|r|}{ P16 school - college } & $P \leq 0.001$ & $P \leq 0.001$ & $P \leq 0.05$ & & & \\
\hline \multicolumn{2}{|r|}{ P15-16 school } & $P \leq 0.001$ & $P \geq 0.05$ & $\mathrm{P} \leq 0.05$ & & & \\
\hline \multicolumn{2}{|r|}{ P15-16 college } & $P \leq 0.001$ & $P \leq 0.001$ & $P \leq 0.01$ & & & \\
\hline \multirow[t]{2}{*}{17} & university $n=58$ & $3.67 \pm 0.15$ & $1.36 \pm 0.16$ & $2.34 \pm 0.16$ & 0 & 58 & 100 \\
\hline & college $n=116$ & $9.09 \pm 0.18$ & $5.26 \pm 0.61$ & $4.12 \pm 0.56$ & $0.31 \pm 0.05$ & 116 & 100 \\
\hline \multicolumn{2}{|r|}{ P17 university - college } & $P \leq 0.001$ & $P \leq 0.001$ & $P \leq 0.01$ & & & \\
\hline \multicolumn{2}{|r|}{ P15-17 college } & $P \leq 0.001$ & $P \leq 0.001$ & $P \leq 0.001$ & & & \\
\hline \multicolumn{2}{|r|}{ P16-17 college } & $P \leq 0.001$ & $P \leq 0.05$ & $P \leq 0.01$ & & & \\
\hline \multirow[t]{2}{*}{18} & university $n=58$ & $4.10 \pm 0.11$ & $0.55 \pm 0.11$ & $2.36 \pm 0.16$ & $0.1 \pm 0.05$ & 58 & 100 \\
\hline & college $n=71$ & $10.74 \pm 0.25$ & $5.01 \pm 0.16$ & $5.52 \pm 0.58$ & $0.70 \pm 0.10$ & 71 & 100 \\
\hline \multicolumn{2}{|r|}{ P18 college - university } & $P \leq 0.001$ & $P \leq 0.001$ & $P \leq 0.001$ & $P \leq 0.001$ & & \\
\hline \multicolumn{2}{|r|}{ P17-18 university } & $P \leq 0.05$ & $P \leq 0.001$ & $P \geq 0.05$ & & & \\
\hline \multicolumn{2}{|r|}{ P15-18 college } & $P \leq 0.001$ & $P \leq 0.001$ & $P \leq 0.001$ & & & \\
\hline \multicolumn{2}{|r|}{ P16-18 college } & $P \leq 0.001$ & $P \leq 0.001$ & $P \leq 0.001$ & $P \leq 0.001$ & & \\
\hline \multicolumn{2}{|r|}{ P17-18 college } & $P \leq 0.001$ & $P \geq 0.05$ & $P \geq 0.05$ & $P \leq 0.001$ & & \\
\hline
\end{tabular}

university graduates. Comparisons of these groups showed significant differences in the dental status of the studied groups. The CFR index of the students of the 1 st year of university was 2.48 times lower (average) than that of the students of the 3rd year of college (very high). The percentage of filled teeth $(\mathrm{F})$ in college was $45.3 \%$ and at university $-63.76 \%$. The number of removed teeth in college students increased 1.9 times compared to 16-year-olds. There were no permanent teeth removed due to caries and its complications in university students. There is a significant increase in the intensity of caries compared to the previous age period in college students (by 34.67\%).

In 18-year-old can be found an increase in the rate of caries intensity compared to 17 -year-olds, but it is less than in previous age groups. At the university students the number of teeth affected by caries increased by 1.12 times, in college - by 1.18 times. The indices remained at medium to very high levels. Attitude to one's dental health is determined by the number of teeth that have been filled and removed teeth due to caries and its complications. There were $51.4 \%$ teenagers attending college treated for dental caries during this age period, and $57.56 \%$ for university students. The number of removed teeth in college students increased 2.26 times compared to the previous age period $(6.52 \%$ of CFR), and in university students were revealed removed teeth $(2.44 \%$ of CFR).

\section{DISCUSSIONS}

The log-linear negative binominal regression model is a favorable methodological instrument to analyze discrete quantitative dependent variables. Such variables do not have a normal distribution to be adjusted in the linear regression model or have a higher variance than the mean, harming therefore the use of Poisson's log-linear regression model due to the overdispersion phenomenon $[21,22]$.

The worst indicators of the disease were seen in children of schools located in the SD with the worst socioeconomic indicators. Other studies conducted in Brazilian cities presented similar results $[23,24]$. An association was also seen between the administrative nature of the school and the caries experience. These results were in agreement with those of the previous studies carried out among 12-year-old schoolchildren, based on the sample of the national survey about oral health in 2003 and in others conducted in Brazilian cities [26-29]. Thus, in the Brazilian environment, the administrative 
nature of the school seems to be a socioeconomic status indicator, together with individual variables, or when their achievement is not possible [28-31].

In this study, findings regarding FHS coverage with OHT were noteworthy, which was associated with a bigger experience of caries among the investigated schoolchildren, regardless of the socioeconomic factors. This can be partially explained because areas with the worst social indicators are priorities for the implementation of FHS. In literature, evidence about the efficacy of oral health actions in FHS is rare and points out for difficulties in their structure, which result in minor or no advances at all in the support model and in the oral health condition of the population [32-34].

The other contextual factors analyzed concerning the presence of oral health programs at school were not statistically associated with the dependent variable. Review studies showed that health education actions alone do not produce long-lasting behavioral changes, therefore they are relatively ineffective [35]. We should emphasize the cross-sectional design of the study, which does not allow establishing causality relations and does not evaluate the required time so that such programs can achieve the desired protective effect. Therefore, the present findings do not invalidate the assessed programs, but show that their probable effectiveness must be evaluated through other parameters as well, besides the health clinical condition of the assisted population.

Differences in the results from the female and male genders confirm the findings of other studies [36-38], and can be motivated through the variable commitment of the parents and society regarding the functional and aesthetical dimensions of oral health for girls and boys [39].

\section{REFERENCES}

1. Volchenko NV, Sokolova YY. Comprehensive assessment of oral hygiene in children studied under different curricula [in Russian]. Journal of Marine Medicine. 2014;1-2(62-63):20-4.

2. Kaskova LF, Artemev AV, Berezhna OE, Amosova LI. Features of the dental status of the population of the territory of Ukraine in different historical epochs [in Russian]. Georgian Medical News. 2014; 12:35-9.

3. Luchynskyy MA, Luchynska YUI, Ostapko OI, Luchynskyy VM. Influence of negative environmental factors on the level of dental morbidity of pediatric population [in Ukrainian]. Bulletin of problems of biology and medicine. 2014;1(2):221-3.

4. Musalymova RS. Influence of subject olympiads on the functional state of the organism of high school students [in Russian]. Hygiene and sanitation. 2012;2:61-3.
As to the influence of maternal education, similar results were reported in studies performed in other Brazilian cities [34]. According to the National Commission on Health Social Determinants, education is strongly associated with the health of the populations [40-41]. Several mechanisms can explain the relationship between indicators of socioeconomic and health status. Furthermore, the causality of this relation is not unique, and there may be interaction between the factors.

Even though race/color has not been associated with the dependent variable, results of the bivariate analysis showed racial differences favoring white subjects, who presented lower prevalence of caries. Likewise, in the national survey performed in 2003, it was seen that black and mulatto adolescents of the Central-West Region had higher chances of presenting non-carious teeth [42]. The explanation for such an association is not clear and may include the influence of socioeconomic position, racial discrimination, health behaviors, among other factors that should be better explored in further studies.

\section{CONCLUSIONS}

The results of the study show that teenagers of different form of study have different attitude to their dental health. Given the intensity of caries, we can assume that teenagers attending college do not pay enough attention to the condition of the hard tooth tissues, which leads to an increase in the number of affected by caries teeth in each studied age period. This leads to a more detailed study of the risk factors for caries in teenagers attending various educational establishments and to plan preventative measures to increase the resistance of the hard tissues of their teeth.

Conflict of interest: none declared Financial support: none declared

5. Mynnybaev TSH, Tymoshenko KT, Honcharova HA. Time budget, academic achievement and adaptation of students of profile classes "School - University" [in Russian]. Hygiene and sanitation. 2012;2:67-9.

6. Smolyar NY, Chukhray NL. Somatic pathology as a factor hampering the formation of permanent tooth enamel resistance [in Russian]. Stomatology. 2017; 96(6):44-7.

7. Chukhray NL. The relationship between the physical properties of oral fluid in children and enamel resistance [in Ukrainian]. Bulletin of Dentistry. 2017;2:41-5.

8. World Health Organization. Oral Health Surveys: Basic Methods. 5th ed. Geneva: World Health Organization; 2015. 125 r.

9. Wolgin M, Fillina N, Shakavets N, Dvornyk V, Lynch E, Kielbassa AM. A systematic review of the caries prevalence among children living in Chernobyl fallout countries. Scientific reports. 2019; 9:1-10. 
10. Thitasomakul S, Thearmontree A, Piwat S et al. A longitudinal study of early childhood caries in 9- to 18-month-old Thai infants. Community Dentistry and Oral Epidemiology. 2006; 34(6):429-36.

11. Wan AKL, Seow WK, Purdie DM et al. A longitudinal study of Streptococcus mutans colonization in infants after tooth eruption. Journal of Dental Research. 2003; 82(7):504-8.

12. Berkowitz R.J. Causes, treatment and prevention of early childhood caries: a microbiologic perspective. Journal of the Canadian Dental Association. 2003; 69(5):304-7.

13. Berkowitz R.J. Mutans Streptococci: acquisition and transmission. Pediatric Dentistry. 2006. 28(2): 106-9.

14. Skeie MS, Espelid I, Skaare AB et al. Caries patterns in an urban preschool population in Norway. European Journal of Pediatric Dentistry. 2005; 6(1):16-22.

15. Cariño KMG. Early childhood caries in northern Philippines. Community Dentistry and Oral Epidemiology. 2003; 31(2):81-9.

16. Berkowitz RJ, Amante A, KopyckaKedzierawski DT et al. Dental caries recurrence following clinical treatment for severe early childhood caries. Pediatr Dent. 2011; 33 (7):510-14.

17. Gussy MG, Water EG, Walsh O et al. Early childhood caries: Current evidence for etiology and prevention. Journal of Paediatrics and Child Health. 2006; 42:37-43.

18. Global strategy for infant and young child feeding. World Health Organization, UNICEF. Geneva, 2003:30.

19. Y Li, PW Caufield, AP Dasanayake et al. Mode of delivery and other maternal factors influence the acquisition of Streptococcus mutans in infants. Journal of Dental Research. 2005; 84(9):806-11.

20. American Academy of Pediatric Dentistry. Policy on early childhood caries (ECC): classification, consequences and preventive strategies. Pediatr Dent. 2009; 30 (7):40-3.

21. American Academy on Pediatric Dentistry, Council on Clinical Affairs. Policy on Use of a Caries-risk Assessment Tool (CAT) for Infants, Children, and Adolescents. Pediatr Dent. 2009; 30 (7):29-33.

22. Poureslami HR, Van Amerongen WE. Early Childhood Caries (ECC) An Infectious Transmissible Oral Disease. Indian J Pediatr. 2009; 76 (2):191-4.

23. Beltrán-Aguilar ED, Barker LK, Canto MT et al. Surveillance for dental caries, dental sealants, tooth retention, edentulism, and enamel fluorosis - United States, 1988-1994 and 1999-2002. MMWR Surveill Summ. 2005;54(3):1-43.

24. Tiberia MJ. Risk Factors for Early Childhood Caries in Canadian Preschool Children Seeking Care. Pediatr. Dent. 2007; 29:201-9.

25. Dye BA, Tan S, Smith V et al. Trends in oral health status: United States, 1988-1994 and 1999-2004. Vital and Health Statistics. 2007;11 (248):92.

26. Zanata R.L, Gasparetto A, Conrado C. Effect of caries preventive measures directed to expectant mothers on caries experience in their children. Brazilian Dental Journal. 2003; 14 (2):75-81.

27. Pitts N, Amaechi B, Niederman R, Acevedo AM, Vianna R, Ganss C et al. Global oral health inequalities: Dental caries task-group research agenda. Adv Dent Res 2011; 23(2):211-20.
28. Freire MCM, Reis SCGB, Gonçalves MM, Balbo PL, Leles CR. Condição de saúde bucal em escolares de 12 anos de escolas públicas e privadas de Goiânia, Brasil. Rev Panam Salud Publica 2010; 28(2):86-91.

29. Cypriano S, Hugo FD, Sciamarelli MC, Tôrres LHN, Sousa MLR, Wada RS. Fatores associados à experiência de cárie em escolares de um município com baixa prevalência de cárie dentária. Ciênc Saúde Coletiva 2011; 16(10):4095-5106.

30. Antunes JL, Frazão P, Narvai PC, Bispo CM, Pegoretti T. Spatial analysis to identify differentials in dental needs by area-based measures. Community Dent Oral Epidemiol 2002; 30(2):133-42.

31. Moura C, Cavalcanti AL, Bezerra PKM. Dental caries prevalence in 12-year-old schoolchildren in the city of Campina Grande, Paraíba, Brazil: A socioeconomic approach. Rev Odonto Ciênc 2008; 23(3):256-62.

32. Merlo J, Chaix B, Yang M, Lynch J, Rástam L. A brief conceptual tutorial of multilevel analysis in social epidemiology: Linking the statistical concept of clustering to the idea of contextual phenomenon. J Epidemiol Community Health 2005; 59(6):443-9.

33. Antunes JL, Peres MA, Mello TRC, Waldman EA. Multilevel assessment of determinants of dental caries experience in Brazil. Community Dent Oral Epidemiol 2006; 34(2):146-52.

34. Moreira RS, Nico LS. Aspectos contextuais da ausência de cárie em escolares de 12 anos no Brasil, em três períodos históricos. Rev Odontol UNESP 2010; 39(5): 263-70.

35. Martins MT, Sardenberg F, Abreu MH, Vale MP, Paiva SM, Pordeus IA. Factors associated with dental caries in Brazilian children: A multilevel approach. Community Dent Oral Epidemiol 2014; 42(4):289-99.

36. Brasil. Ministério da Saúde. Secretaria de Atenção à Saúde. Departamento da Atenção Básica. SB Brasil 2010: Resultados principais. Brasília: Ministério da Saúde; 2011.

37. Szwarcwald CL, Damacena GN. Amostras complexas em inquéritos populacionais: Planejamento e implicações na análise estatística dos dados. Rev Bras Epidemiol 2008; 11(Suppl 1):38-45.

38. Rasbash J, Charlton C, Browne WJ, Healy M, Cameron B. MLwiN Version 2.02. Bristol: Centre for Multilevel Modeling; 2005.

39. Victora CG, Huttly SR, Fuchs SC, Olinto MT. The role of conceptual frameworks in epidemiological analysis: A hierarchical approach. Int J Epidemiol 1997; 26(1):224-7.

40. GschlößI S, Czado C. Modelling count data with overdispersion and spatial effects. Stat Pap 2008; 48:531-52.

41. Piovesan C, Pádua MC, Ardenghi TM, Mendes FM, Bonini GC. Can type of school be used as an alternative indicator of socioeconomic status in dental caries studies? A cross-sectional study. BMC Med Res Methodol. 2011;11:37.

42. Pereira CRS, Roncalli AG, Cangussu MCT, Noro LRA, Patrício AAR, Lima KC. Impacto da Estratégia de Saúde da Família sobre os indicadores de saúde bucal: Análise em municípios do Nordeste brasileiro com mais de 100 mil habitantes. Cad Saúde Pública 2012; 28(3):449-62. 